Eurasscience Journals

Eurasian Journal of Forest Science (2015) 3(2): 1-11

\title{
SEASONAL VARIATION IN LIGHT TRANSMISSION AND CANOPY GAPS OF DECIDUOUS ROADSIDE VEGETATION: ASSESSMENT WITHIN FOREST LANDSCAPE
}

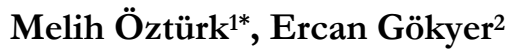 \\ ${ }^{1}$ Assist. Prof. Dr., Bartın University, Faculty of Forestry, Department of Landscape Architecture, Division of Landscape \\ Techniques, Room No: 314, 74100, Bartın, Turkey, Corresponding author: melihozturk@bartin.edu.tr* \\ 2 Assist. Prof. Dr., Bartın University, Faculty of Forestry, Department of Landscape Architecture, Division of Landscape \\ Techniques, Room No: 303,74100, Bartın, Turkey egokyer@bartin.edu.tr
}

\begin{abstract}
Based on the sunlight duration, percentage of light transmission and canopy gaps vary within the phenological stages involving budburst, flushing, leaf development, senescence, fading and leaf fall. In this study, the seasonal pattern of light transmission and canopy gaps of deciduous vegetation along a rural road section was monitored. The rural road is surrounded by forest landscape and, connects Bartın and Safranbolu cities. The road is located within the Bartın watershed of Turkey. Hemispherical photographing and image processing techniques were used to analyze the percentage of light transmission and canopy gaps throughout a foliage year in between 2012 and 2013. During 22 field visits, 220 hemispherical photographs were taken from 10 points along $700 \mathrm{~m}$ of the experimental site. Percentage of light transmission, and canopy gaps data were evaluated together with the daily sunlight duration data from the meteorological station. The correlation ( $r$ ) between mean sunlight duration (msd) and the percentage of mean light transmission $(m p l t)$ were -0.68 . On the other hand, the correlation $(r)$ between mean sunlight duration $(m s d)$ and the percentage of mean canopy gaps $(m p c g)$ were -0.75 . Both of the correlations were highly significant $(P<0.01)$. The seasonal patterns of mplt, mpcg, and $m s d$ were assessed considering both the roadside vegetation and the surrounding landscape, emphasizing travelers' and drivers' perceptions.
\end{abstract}

Keywords: deciduous canopy, hemispherical photographs, intercity road, rural landscape, seasonal patterns

\section{INTRODUCTION}

Roads are the linear linkages between social elements, such as populations, societies, cultures, and economies (Havlick 2002, Delgado et al. 2007). Not only they serve the purpose of transportation, but they also may introduce astonishing landscapes for the travelers to view. Within this perspective, rural landscapes, particularly the forested ones, offer visual displays that change due to the spatial and temporal variations (Marsh 2010). Experiencing these unique features of the landscape along the road allows travelers to enjoy the natural beauty of the environment, ultimately gives them a sense of recreational contentment. Unfortunately, disturbing rural landscapes by constructing roads causes some negative impacts. The ecological consequences of road construction involve landscape fragmentation through generating discrete patches and habitats (Forman and Alexander 1998; Forman and Deblinger 2000). It also results in the introduction of non-native plant species (Forman and Godron 1981, Hansen and Clevenger 2005, Christen and Matlack 2009). Dust and noise pollution (Forman and Alexander 1998) and the warming effect of the road's surface (Delgado et al. 2007) are among the environmental problems associated with road construction. Although the numerous adverse ecological and environmental impacts of road construction, particularly paved and 
asphalt roads, have been addressed by many researchers, their recreational role and value should not be ignored.

Beyond travelers' positive impressions of the landscapes that can be seen from rural roads, the influence of the vegetation on the drivers' perceptions, particularly of the vegetation near the roadway, have been of interest to many researchers. Out of those who deal with the environmental behavior and psychology (e.g. Mok et al. 2006, Antonson et al. 2009) are remarkable. Roadside vegetation, which is well-suited as a component of the overall forest landscape, is one of the unique features along the roadway, and it contributes to drivers' perceptions of the landscape and nature (Wolf 2003). Roadside vegetation that is adequately dense and relatively uniform allows the driver concentrate on the road. However, according to some researchers, such vegetation has some negative impacts on drivers. Drivers have been shown to experience higher stress when driving on roads with roadside vegetation that when driving on roads surrounded by open spaces (Antonson et al. 2009).

Deciduous vegetation has a significant role on light transmission (Link et al. 2004). Namely, after vegetation begins to foliate in the spring, the percentage of the gaps within their canopy gradually decreases, reaching a minimum in the summer (Waring and Running 2007). Theoretically, the closer the canopy, the lower the amount of light that penetrates beneath the canopy will be (Kucharik et al. 1999). Hence, light intrusion through deciduous vegetation is the lowest in the summer. The defoliation of the vegetation begins in autumn, and this leads to increases in the percentage of the gaps, which allows more light intrusion beneath the canopy. The increase in the gap percentage proceeds gradually until the vegetation becomes almost completely leafless in the winter (Bonan et al. 2002). Drivers' vision can be impaired by the glare that results from their exposure to direct sunlight (Jurado-Piña et al. 2010). In addition, road surfaces warm rapidly under direct sunlight. However, both the duration and intensity of light are reduced in the winter, so the negative effects of direct sunlight beneath the canopy are diminished somewhat (Hutchison and Matt 1977). The relatively low temperatures in the winter prevent the surfaces of road from transferring much heat to the surroundings. Nevertheless, it is undeniable that the canopy provided by vegetation has a crucial cooling role by providing shade at the time that air temperatures are increasing (Oke 1989).
In this study, the seasonal patterns of light transmission and canopy gaps were monitored, analyzed, and assessed for deciduous vegetation. In the Bartın watershed of Turkey, the deciduous vegetation is aligned along the roadside, forming alleys within the forest landscape. The seasonal changes in light transmission and canopy gaps were monitored throughout the year. The monitoring processes were conducted by taking relatively frequent hemispherical photographs throughout the year. The analysis procedure involved scanning the digital hemispherical photographs using image-processing software. The seasonal light transmission and gap patterns of deciduous roadside vegetation and the duration of sunlight were evaluated, and their roles were considered within the overall forest landscape.

\section{MATERIAL AND METHODS}

\section{Site Characteristics}

The study site was located within the Bartin watershed in northwestern Turkey (Fig. 1). It was on an intercity rural road that connects the cities Bartin and Safranbolu. The length of this rural road is $15 \mathrm{~km}$, and it is covered by a canopy that consists primarily of Oriental Plane (Platanus orientalis L.). There are a few interruptions in the canopy where indigenous planes were not present on one side or on both sides of the road. The secondary vegetation along the roadside is primarily oak trees (Quercus sp.) and European Hornbeam trees (Carpinus betulus). The plane road extends from a point that is $38 \mathrm{~km}$ from Bartin Province to a point that is $37 \mathrm{~km}$ from Safranbolu World Heritage City (UNESCO 1995). The Ovacuma River, a tributary of the Bartın Stream, runs alongside the road. Consequently, alluvium is the major soil in the site (TMFAL 2005; TGDMRE 2007). The river flows five to ten meters below the road and laterally approaches closer to the road at various locations. This research focused on about $700 \mathrm{~m}$ of this plane road, and 10 hemispherical photographing points were selected for monitoring the seasonal changes in light transmission and canopy gaps.

The test section of the road and river is surrounded by hills with northern and southern aspects. Oak (Quercus sp.), Oriental Beech (Fagus orientalis), European Hornbeam (Carpinus betulus), and Black Pine (Pinus nigra) trees constitute the pure and mixed stands of the surrounding forest landscape (Fig. 1) (TGDF 2006). The seasonal foliage and color patterns of these forest landscapes are made especially attractive by the scenic 
beauty of the oaks and hornbeams. At the lowest altitude (above sea level) of the study area, the levels of the river and the road are approximately 210 and $220 \mathrm{~m}$, respectively. The highest altitude, the crests of the hills, range from 450 to $520 \mathrm{~m}$. Consequently, the slope of the surrounding hills is relatively steep, ranging from 20 to $35 \%$. The average annual precipitation is about 1044 $\mathrm{mm}$, and the average temperature of the site is about $13^{\circ} \mathrm{C}$ (TSMS 2013). The wettest month is October, with a mean precipitation of $123 \mathrm{~mm}$, and the hottest month is July, which has a mean temperature of about $22^{\circ} \mathrm{C}$ (TSMS 2013). Rural settlements also exist around the site in the form of distinct villages. These settlements are integrated within the composition of the rural landscape. Not only the forms but also the colors of the trees in the forest and the houses in the villages exhibit spectacular harmony.

The Oriental Plane is a vigorous tree that has a relatively large canopy and leaves that have coarsely dentate lobes (Tutin et al. 1993). The glossy green leaves (Boyd et al. 1996) turn into yellowish brown during defoliation in the autumn. The amazing bark of these trees has various colors, including flaking grey, brown, and cream (Boyd et al. 1996). It is widespread along the sides of rivers in the northwestern of Black Sea area of Turkey (Yaltırk and Efe 2000). The lengths of the indigenous Oriental Planes along the roadside reach up to $20 \mathrm{~m}$, and there is a mixture of mature and young trees. They essentially form a green tunnel through which the road passes, particularly from late spring until mid-autumn. Given the vast canopy, they generate dark shadows on the road. In addition, synchronized with the undulating topography, they present brilliant and exciting perspectives alongside the road. They spread around the river channel forming plane islands between the road and the river (Fig. 1).

The width of the road is approximately six meters, so it is a two-lane road, with one lane for each direction. There is no extra artificial lighting alongside the road. Hence, drivers are obliged to turn on their vehicles' headlights beginning in the evening. Therefore, the headlights of the vehicles traveling in the opposite direction can be a concern for drivers since there is no central refuge, vegetation, or barrier between the two lanes. The road is used for public transportation and for industrial and commercial transportation. Thus, there are trucks, buses, and cars on the road. With such a narrow road being traveled by all types of vehicles, accidents are inevitable. Despite these possible negative impacts, there are very pleasant integrated river and forest landscape features behind and beyond the screening trees along the road.

\section{Hemispherical Photography}

The hemispherical photographing technique for the determination of light transmission of forests is a common methodology used by many researchers (Dignan and Bren 2003, Promis et al. 2009). The principle of the methodology depends upon the calculation of the percentage of light transmission through the canopy gaps. Consequently, it is based on distinguishing the sky from the vegetation in photographs taken in the upward direction (Schleppi et al. 2007). This is conducted by using software that is designed to process and analyze images. Hemispherical photographs $\left(180^{\circ}\right)$ were taken using a digital SLR camera (Canon EOS 5D Mark II-Canon Corporation) on which an 8-mm fisheye objective (Sigma F3.5 EX DG Circular Fisheye-Sigma Corporation) was mounted. Hemisfer software, version 1.5.3 (Swiss Federal Institute for Forest, Snow and Landscape Research) (Schleppi et al. 2007) was used to analyze the hemispherical photographs. Automatic thresholding based on the study of Nobis and Hunziker (2005) was used during the analysis of the digital photographs.

For the determination of the percentages of light transmission and canopy gap, 10 points were defined along the $700 \mathrm{~m}$ experimental site. The distances between the points varied from 50 to $75 \mathrm{~m}$. Out of those 10 points, only the hemispherical photographs of the seventh and eighth points showed oaks and European Hornbeams as being secondary trees after the Oriental Planes. The hemispherical photographs at the other eight points showed only Oriental Planes. The exact locations of the points where the photographs were made were defined based on the use of a global positioning system and the traffic signs along the road.

Throughout the study, 22 field visits were made and 220 hemispherical photographs were taken. Many of these visits occurred in mid-spring (end of March) and early summer (end of June) when the budburst, flushing, and development stages of the leaves occur sequentially. Since the transitions between these stages flow rapidly, it was essential to take photographs frequently. Therefore, photographs were taken at almost weekly intervals, and they were finalized after 14 field visits. Relatively less frequent photographing was performed during senescence, fading, and fall stages of the leaves. The stages involved the period between mid-summer (end of July) and late winter (end of 


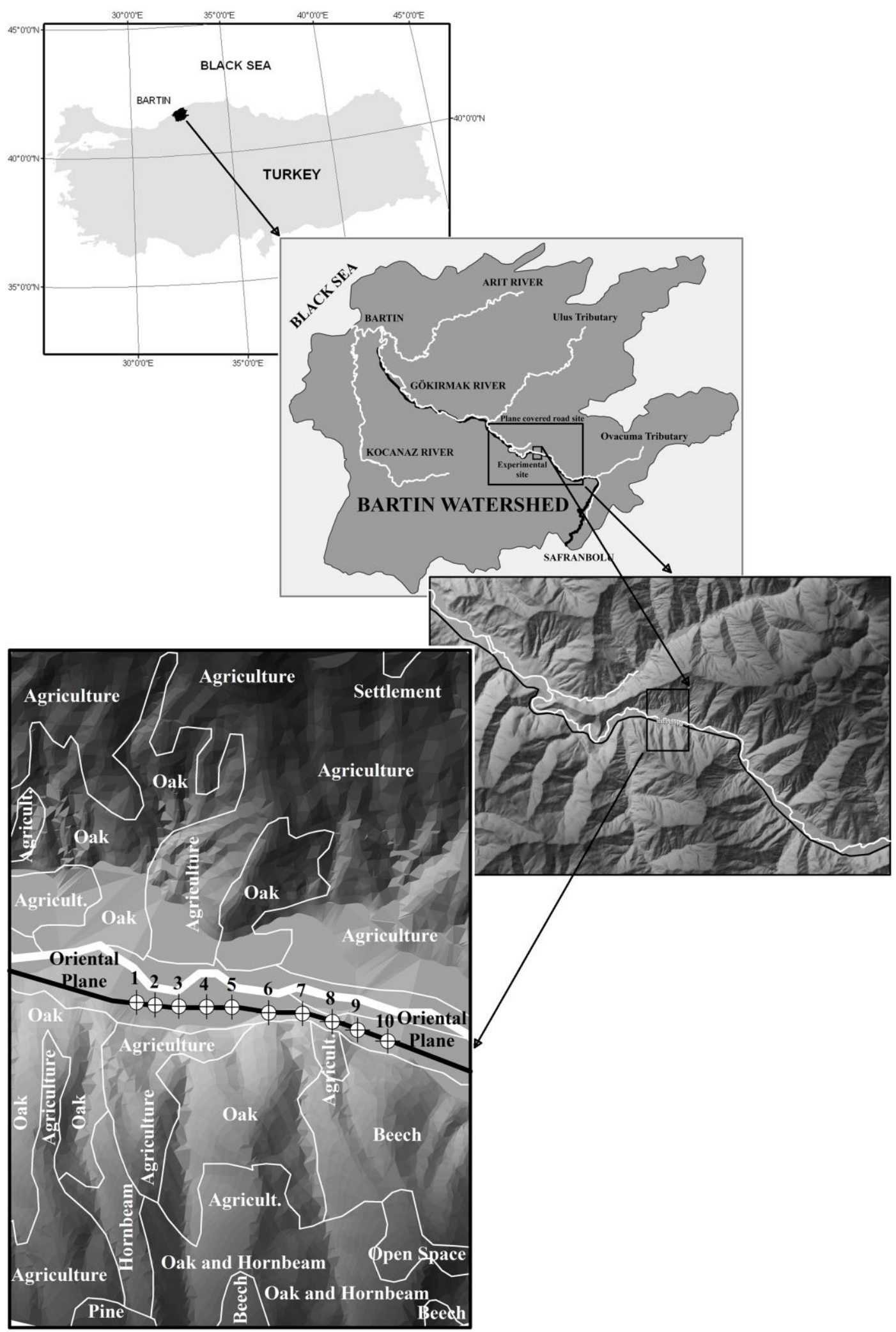

Figure 1. Location of photographing points, experimental site within the Bartın watershed and Turkey. eurasscience.com 
February) when photographs were taken at essentially monthly intervals. This second period was finalized after eight field visits. The exact dates and times of the field visits were defined based particularly on the weather conditions. Rainy and snowy days were inconvenient for taking photographs. Photographs were not taken during the mid-day periods of sunny days in order to avoid direct exposure to sunlight when taking the photographs.

SPSS 16.0 software (SPSS Inc., Chicago, IL) was used for the statistical analyses. The Pearson correlations between percentage of light transmission and percentage of gaps were defined, as were the correlations between the duration of the daily sunlight, the percentage of light transmission, and the percentage of gaps (Devore and Farnum 1999). Assessing the significance of the differences among the values was also performed.

\section{RESULTS}

The 'foliage year' is the annual period that began on March 25, 2012, when the first photographs were taken at the 10 points. The period extended through February 23, 2013, when the final photographs were taken. Throughout this foliage year, 22 field visits were made, and 220 hemispherical photographs were taken and analyzed. The data for the percentages of light transmission and canopy gaps acquired from those analyses were evaluated together with the data of mean sunlight duration from the meteorological station (TSMS 2013) for the foliage year. The mean percentages of light transmission and canopy gaps are the averages of the 10 points at which photographs were taken. Fig. 2 shows the seasonal patterns of the mean light transmission and canopy gap percentages together with the mean sunlight duration data. The mean sunlight duration is the average of the data for the interval between the corresponding date and the previous date when photographs were taken. For the first date that photographs were taken, the mean sunlight duration was the average for the previous week.

The mean percentage of light transmission (mplt) began to decrease gradually. It was about $86 \%$ when the first photographs were taken on March 25, and it was about $79 \%$ when the third photographs were taken on April 14. The mean percentage of canopy gaps ( $\mathrm{mpcg}$ ) diminished slightly from $35 \%$ to about $33 \%$ during this same 20-day period. The decrease in the mplt was followed by a relatively sharp subsequent decline down to about $32 \%$ on May 11 . The relatively sharp decline in the mplt indicated that the canopy gaps were closing. In addition, the number increment and growth processes of leaves were more intensive during one month period than they were for the rest of the foliation period. Again, a gradual, slight decline in the mplt (from about $32 \%$ to about $26 \%$ ) occurred in the subsequent 45 days, when the closing of some of the remaining holes in the canopy gap was noted (with $m p c g$ decreasing from about $19 \%$ to about $15 \%$ ).

After June 30, mplt and mpcg gradually increased each month, indicating that defoliation was taking place slowly. After approximately three months, mplt and $m p c g$ had increased slightly to about 32 and $18 \%$, respectively. During the subsequent three months after September 27 , both the mplt and $m p c g$ increased rapidly up to about 74 and $35 \%$, respectively. Consequently, one-third openness in the canopy led to $75 \%$ light penetration under the canopy. During this period, the deciduous trees gradually became yellowish brown and finally lost all of their leaves. The incremental increase in both the $m p l t$ and $m p c g$ was sustained throughout January and February 2013, eventually reaching about 80 and 36\%, respectively.

The mean sunlight duration ( $m s d$ ) fluctuated during the first two and a half months during the foliation. The msd values ranged between about 5.3 and $9.5 \mathrm{~h} /$ day during this period. However, during the last two weeks of the foliation stage, msd increased consistently from about 7 to $12 \mathrm{~h} /$ day. After this short stage, defoliation started slowly, and msd decreased consistently down to about $8.8 \mathrm{~h} /$ day by September 27. The decrease proceeded sharply during the subsequent three months, finally reaching about $2.2 \mathrm{~h} /$ day. The $m s d$ values were almost constant at about $2 \mathrm{~h} /$ day along for the last two months of the foliage year, i.e., January and February of 2013. There was a negative correlation between $m s d$ and mplt-mpcg. The correlation coefficients $(r)$ between msd and $m p l t-m p c g$ were -0.68 and -0.75 , respectively. The respective differences revealed the significance of these correlations $(P<0.01)$.

\section{DISCUSSION}

Trees appear to be immobile living creatures in nature. However, the various species gain spatial and temporal mobility through the regeneration process, which allows them to spread from one area to another. Even so, individual trees are spatially stagnant. Although the growth of wood and shoots provides them with temporal dynamics, these processes are rather slow and 
cannot be sensed by the human eye. Nevertheless, budburst, flushing, development, senescence, fading, and fall stages of tree leaves, particularly deciduous trees, can be observed even in a relatively short period

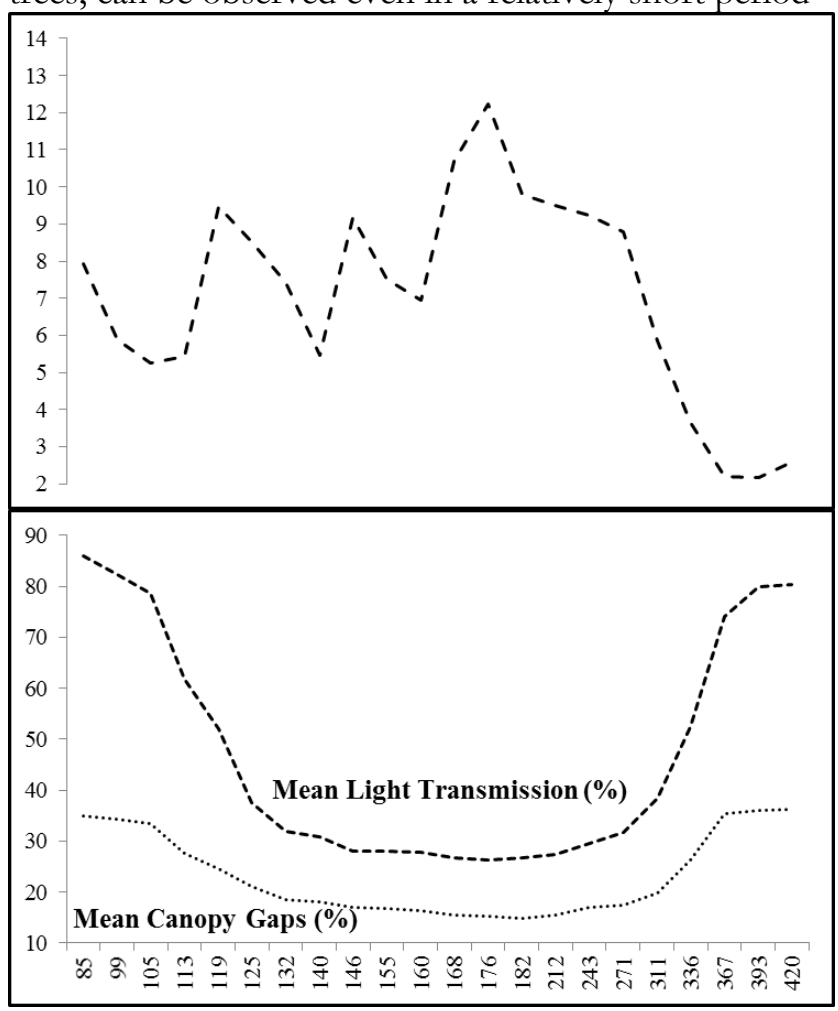

Figure 2. Mean sunlight duration together with mean percentages of light transmission and canopy gaps.

of time. Consequently, seasonal leaf variations supply mobility to deciduous trees and dynamic landscapes to viewers.

The deciduous trees along the roadsides contribute to the travelers' perception directly due to these phenological changes and indirectly by the effects of changes in light transmission and canopy gaps. Confirming the relation between the phenology and the sunlight, Öztürk et al. (2015) determined relatively high correlation $(r=0.79)$ between the instant sizes of the Carpinus betulus L. leaves and the preceding year's mean sunlight duration within the close region to our research area. Sunlight penetrating beneath the canopy gaps turns into flashes, generating animation for the travelers on the road. In addition, altering of the gaps within the canopy leads to the sky's appearing and disappearing, thereby promoting this animation. During the budburst stage of the roadside canopy (during the first half of April), mplt decreased by only $10 \%$, while the $m p c g$ closed by only about $2 \%$. However, about $25 \%$ of the day was sunny. During that stage, the leafless trees along the roadside did not block the surrounding scenery. The surrounding forest vegetation also was leafless, except for the Black Pines. Based on a simulator study, Antonson et al. (2009) reported that the landscape varying between forested and open areas put more stress on drivers than solely the forested or open landscapes.

The flushing stage of the roadside canopy (during the second half of April) was more glamorous than the previous leafless stage. Silent and impressive flushing was composed with the abundant water in the river oscillating between livid color and turquoise. Both the $m p l t$ and $m p c g$ decreased by about $50 \%$, whereas $m s d$ occupied almost one-third of the day. However, this silent change causes travelers and drivers to respond with discrete perceptions. Unfortunately, the transformations that are occurring along the roadside, while enjoyable for travelers, may distract the attention of drivers. Conversely, Mok et al. (2006) stressed that landscape changes contributed to drivers' visual perception based on comparisons that were made before and after crashes. Cackowski and Nasar (2003) supported the idea that, in some way, roadside vegetation had restorative effects on drivers' level of frustration.

Beyond the flushing stage, deep and dark greenery covered the road throughout May and June, when the leaves developed in size and number. Only approximately $25 \%$ of the sunlight passed through the $15 \%$ gap and reached beneath the roadside canopy. The maximum msd slightly exceeded half a day during this development stage. Fig. 3 demonstrates the three landscapes and all of the hemispherical photographs of the 10 points for three dates, i.e., June 8, 2012, December 1, 2012, and February 23, 2013, indicating that instantaneous situation. The first photographs were taken from the first until the fourth point, the second photographs were taken from the third until the sixth point, and the third photographs were taken from the seventh until the tenth point. The surrounding vegetation became almost invisible behind the canopy (Fig. 3a), whereas the river water retreated down to the bed becoming very shallow. Confined in a green tunnel, the drivers may concentrate on the road ahead, but continuous confinement is monotonous for travelers and drivers, even under the greenery. In addition, the road is located in the east-west direction (Fig. 1), so morning drivers going east will be facing the sun and afternoon drivers will be facing the sun going west, which could obstruct their vision. 


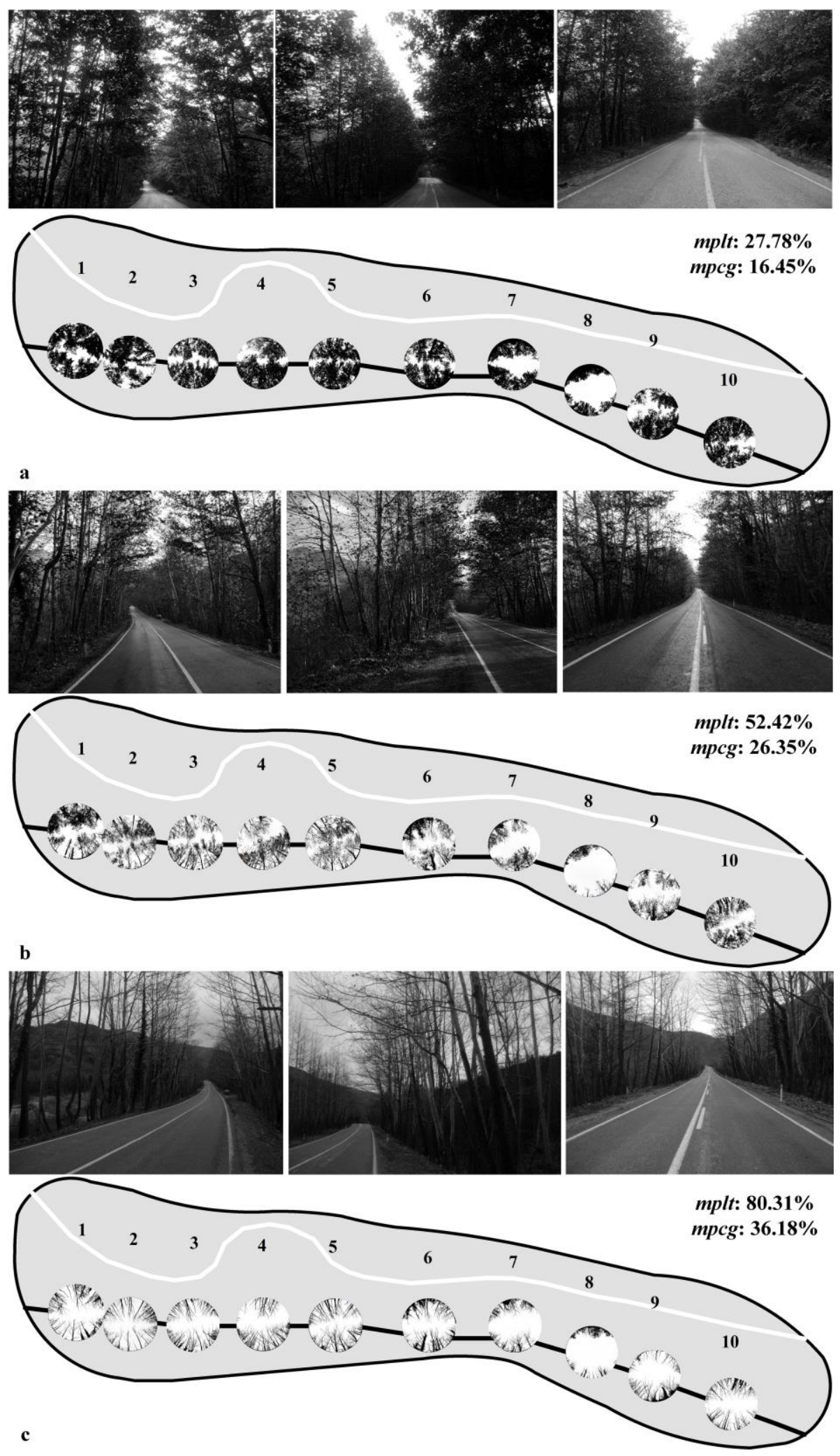

Figure 3. Landscape and hemispherical photographs of 10 points for June 8th 2012 in a, for December 1st 2012 in b, and for February 23rd of 2013 in c. 
After all of the leaves of the roadside vegetation were fully developed in size and number, the senescence stage lasted for about three months, i.e., July, August, and September as also indicated by Öztürk (2015) for the same region. This stage was associated with the phenomenon that the color of some leaves turned from glossy green into pale green, and a few leaves fell due to weather conditions, such as wind and temperature. Thus, only about a $5 \%$ increase in the mplt and a $3 \%$ increase in the mpcg occurred, whereas msd remained almost constant, increasing by only $1 \mathrm{~h} /$ day during the last month of this stage. Such slight differences within the overall roadside canopy indicate almost no change from the perspectives of travelers and drivers. However, in the following three months until the beginning of 2013, both the fading and falling processes progressed simultaneously. The $m p l t$ increased by about $250 \%$, and mpcg increased by more than 200\%. Also, the msd decreased to about $2 \mathrm{~h} /$ day. The colors of both the roadside canopy and the surrounding forest vegetation underwent dramatic transitions. First they blanched and turned to a yellowish color and finally became yellowish brown before they fell. Chen and Jim (2008) indicated the same autumn leaf color characteristics for another plane (Platanus $x$ acerifolia), which forms a green tunnel along the West Beijing Road in Nanjing (China). The surrounding forest landscape again took place in the background (Fig. 3b) harmonized with the recharged river. The eventual roadside vegetation and the composition of the forest-river landscape produced incredible colors for the travelers to enjoy, and the scattered rural houses completed the beautiful picture. As indicated by Velarde et al. (2007), such natural landscapes contribute to the health of the viewers. However, such diversity in the overall landscape may pose considerable risks for drivers, since it can lead to disorganization within their perception.

During the final two months of the fall stage, i.e., January and February 2013, the trees and vegetation were almost leafless (Fig. 3c). The situation was almost the same as the beginning of the foliage year except for the msd. The msd was slightly greater than $2 \mathrm{~h} /$ day, whereas it was almost $8 \mathrm{~h} /$ day at the beginning of the foliage year, so the travelers and particularly the drivers were exposed to sunlight under an open roadside canopy.

\section{CONCLUSIONS}

Many landscape researchers have proposed planning strategies for the road landscapes (Ahern, 1995). They have concentrated principally on the greenway concept, and they have emphasized the significance of these landscapes within the ecological, recreational (Viles and Rosier 2001, Jim and Chen 2003), historical, and economical-transportation ( $\mathrm{Yu}$ et al. 2006) contexts. Roadside vegetation is one of the major factors in planning the landscaping of roads. In addition to positive and negative impacts on travelers/drivers through concentrating or distracting perception, their role on establishing connection with or isolation from surrounding landscape cannot be ignored.

In this study, not only the seasonal effects of roadside vegetation on travelers/drivers but also their integration with background forest and river landscapes were considered. The study involved the analysis of light transmission, canopy gap parameters, the duration of sunlight. However, a more comprehensive investigation of the influences of roadside vegetation on travelers/drivers could be based on behavioral testing. Further analyses that merge travelers'/drivers' behavioral testing with broader ecological, vegetative, and meteorological variables would be beneficial in addressing sustainable road landscape planning objectives. Furthermore, subsequent studies within this area also should have a significant focus on conservation of the roadside vegetation, which is threatened because of the government's plans to enlarge roads. 


\section{Yapılandırılmış Özet}

Önem: Yol kenarı bitki örtüsünün hem araçların güvenli ve konforlu seyir yapmaları hem de yakın çevredeki peyzajın yolcular tarafindan algilanması yönlerinden önemlidir. Bilhassa yaprak döken bitki örtüsünün yıl boyunca ve mevsimlik olarak, yaprak boyut ve sayı itibariyle değişkenlik göstermesi ş̧1k geçirgenliği ve tepe çatısı boşluğu üzerinde kayda değer etkisi söz konusudur.

Amaç ve Hedef: Orman peyzajı ile çevrili ve iki şehri birbirine bağlayan kırsal bir yol kesiti boyunca yaprak döken bitki örtüsünün ıșık geçirgenliği ve tepe çatısı boşluğunun mevsimlik desenleri izlenmesi amaçlanmıştır. Aynı zamanda, bitki örtüsünün ışık geçirgenliği ve tepe çatısı boşluk yüzdeleri ile meteorolojik parametrelerden güneşlenme süresi arasında korelasyon ortaya koymak hedeflenmiştir.

Materyal: Çalışma alanı, Türkiye'nin kuzeybatısında yer alan Bartın Havzası içerisinde, Bartın ile Safranbolu şehirlerini birbirine bağlayan ve ağırlıklı olarak Doğu Çınarlarının (Platanus orientalis L.) karşılıklı olarak dizildiği yol üzerindeki yaklaşı 700 m'lik deneme kesitidir. Alanın deniz seviyesinden ortalama yüksekliği $220 \mathrm{~m}$ olup, çevreleyen tepelerin en yükseği 520 m'dir. Bölgede yıllık toplam yağış ortalama $1044 \mathrm{~mm}$ ve yıllık ortalama sıcaklık $13^{\circ} \mathrm{C}^{\prime}$ dir.

Metot: Yol kenarındaki deneme kesitinde bulunan bitki örtüsü altında 1şık geçirgenliği ve tepe çatıs1 boşluğunu tespit etmek amacıyla yarıküre fotoğraflama ve görüntü işleme teknikleri kullanılmıştır. Yarıküre fotoğraflar, dijital SLR kamera üzerine monte edilen 8-mm balıkgözü objektif kullanılarak bitki örtüsü altından çekilmiştir. Yol kesiti üzerinde 50 ile $75 \mathrm{~m}$ aralıklarla belirlenen 10 farklı sabit noktaya yıl içerisinde 22 defa gidilerek, toplamda 220 fotoğraf çekilmiştir. Çekilen fotoğraflar ise Hemisfer 1.5.3 yazılımı kullanılarak analiz edilmiş ve 1ş1k geçirgenliği ve tepe çatısı boşluk yüzdeleri elde edilmiştir. Çalışmadaki istatistiki analizler ise SPSS 16.0 yazılımı kullanılarak gerçekleştirilmiştir.

Bulgular: Çalışmanın başlangıç tarihleri olan Mart ayının sonlarında bitki örtüsünün ışık geçirgenliği ve tepe çatısı boşluğu sırasıyla \%86 ve \%35 olmak üzere yüksek seviyelerdedir. Bu tarihlerde ortalama güneşlenme süresi 5.3 saat/gündür. Işık geçirgenliği ve tepe çatısı boşluğu, yapraklanmanın tamamlandı̆̆1 Haziran ayının sonlarında sırasıyla $\% 26$ ve $\% 15$ gibi en düşük seviyelere inmiştir. Bu tarihlerde günün yarısından fazlası güneşlidir (12.2 saat/gün). Çalışmanın tamamlandığ1 Şubat ayının sonlarında ise ışık geçirgenliği ve boşluk oranı sırasıyla tekrar $\% 80$ ve \%36 seviyelerine ulaşmış, bu tarihlerde ortalama güneşlenme süresi 2.2 saat/güne kadar düşmüştür. Ortalama güneşlenme süresi (ogs) ve 1) ortalama ışı geçirgenliği yüzdesi (o1gy) ve 2) ortalama tepe çatısı boşluğu yüzdesi (otçby) arasindaki korelasyonlar (r) sırasıyla -0.68 ve -0.75 'dir. Her iki korelasyon da yüksek önemlilik $(\mathrm{P}<0.01)$ düzeyinde çıkmıstır.

Sonuç ve Öneriler: Bu çalışmada sadece yol kenarı bitki örtüsünün 1şık geçirgenliği ve tepe çatısı boşluğunun yolcu ve sürücüler üzerindeki mevsimlik etkilerine değinilmemiş, aynı zamanda bu yol kenarı bitki örtüsünün arka planında yer alan orman ve ırmak peyzajı ile ortak kompozisyonuna da vurgu yapılmıştır. Bununla birlikte, yol kenarı bitki örtüsünün yolcu ve sürücüler üzerindeki etkilerinin incelendiği davranış analizlerine dayalı daha kapsamlı araştırmalara ihtiyaç vardır. Sürdürülebilir yol peyzaj planlaması hedefleri doğrultusunda, yolcu ve sürücülerin davranışlarının ekolojik, bitkisel ve meteorolojik değişkenlerin harmanlandığı gelişmiş analizlerle ortaya konulmasi gerekmektedir. 


\section{Acknowledgments}

The Turkish General Directorate of Forestry (TGDF) and the Turkish State Meteorological Service (TSMS) are acknowledged for the data they provided in support of the objectives of the study.

\section{References}

Ahern, J. (1995). Greenways as a planning strategy. Landscape and Urban Planning, 33, 131-155.

Antonson, H., Mårdh, S., Wiklund, M., Blomqvist, G. (2009). Effect of surrounding landscape on driving behavior: A driving simulator study. Journal of Environmental Psychology, 29, 493-502.

Bonan, G., Levis, S., Kergoat, L., Oleson, K.W. (2002). Landscapes as patches of plant functional types: an integrating concept for climate and ecosystem models. Global Biogeochemical Cycles, 16, 1021-1044.

Boyd, P., Byles, M., Cheifetz, A., Chisholm, J., Copland, A., Double, C., Frances, P., Gavira, A., Hammond, R., O’Hanlon, M., Hawthorne, L., Paxton, S., Riley, L., Stewart-Jones, H., Weeks, J., Whitehorn, T., Widdicombe, S., Wild, F. (1996). The A-Z Plant Directory. Dorling Kindersley Ltd., London, UK.

Cackowski, J.M., Nasar, J.L. (2003). The restorative effects of roadside vegetation: Implications for automobile driver anger and frustration. Environment and Behavior, 35, 736-751.

Chen, J.M., Cihlar, J. (1995). Quantifying the effect of canopy architecture on optical measurements of leaf area index using two gap size analysis methods. IEEE Transactions on Geoscience and Remote Sensing, 33, 777787.

Chen, S.S., Jim, C.Y. (2008). The urban forest of Nanjing City: Key Characteristics and Management Assessment. In: Carreiro, M.M., Song, Y.C., Wu, J. (Eds.), Ecology, Planning, and Management of Urban Forests, International Perspectives. Springer Science+Business Media, LLC, New York, USA, pp. 259-278.

Christen, D.C., Matlack, G.R. (2009). The habitat and conduit functions of roads in the spread of three invasive plant species. Biological Invasions, 11, 453465.

Delgado, J.D., Arroyo, N.L., Arévalo, J.R., FernándezPalacios, J.M. (2007). Edge effects of roads on temperature, light, canopy cover, and canopy height in laurel and pine forests (Tenerife, Canary Islands). Landscape and Urban Planning, 81, 328-340.

Devore, J., Farnum, N. (1999). Applied Statistics for Engineers and Scientists. Duxbury Press, USA.

Dignan, P., Bren, L. (2003). Modelling light penetration edge effects for stream buffer design in mountain ash forest in southeastern Australia. Forest Ecology and Management, 179, 95-106.

Forman, R.T.T., Godron, M. (1981). Patches and structural components for a landscape ecology. Bioscience, 31, 733-740.

Forman, R.T.T., Alexander, L.E. (1998). Roads and their major ecological effects. Annual Review of Ecology and Systematics, 29, 207-231+C2.

Forman R.T.T., Deblinger, R.D. (2000). The ecological roadeffect zone of a Massachusetts (U.S.A.) Suburban Highway. Conservation Biology, 14, 36-46.

Hansen, M.J., Clevenger, A.P. (2005). The influence of disturbance and habitat on the presence of nonnative plant species along transport corridors. Biological Conservation, 125, 249-259.

Havlick, D.G. (2002). No Place Distant: Roads and Motorized Recreation on America's Public Lands. Island Press, Washington, USA.

Hutchison, B.A., Matt, D.R. (1977). The distribution of solar radiation within a deciduous forest. Ecological Monographs, 47, 185-207.

Jim, C.Y., Chen, S.S. (2003). Comprehensive greenspace planning based on landscape ecology principles in compact Nanjing city, China. Landscape and Urban Planning, 65, 95-116.

Jurado-Pina, R., Pardillo-Mayora, J., Jiménez, R. (2010). Methodology to analyze sun glare safety problems at highway tunnel exits. Journal of Transportation Engineering, 136, 545-553.

Kucharik, C.J., Norman, J.M., Gower, S.T. (1999). Characterization of radiation regimes in nonrandom forest canopies: theory, measurements, and a simplified modeling approach. Tree Physiology, 19, 695-706.

Link, T.E., Marks, D., Hardy, J.P. (2004). A deterministic method to characterize canopy radiative transfer properties. Hydrological Processes, 18, 3583-3594.

Marsh, W.M. (2010). Landscape Planning, Environmental Applications. John Wiley and Sons, USA.

Mok, J.H., Landphair, H.C., Naderi, J.R. (2006). Landscape improvement impacts on roadside safety in Texas. Landscape and Urban Planning, 78, 263-274.

Nobis, M., Hunziker, U. (2005). Automatic thresholding for hemispherical canopy-photographs based on edge detection. Agricultural and Forest Meteorology, 128, 243-250.

Oke, T.R. (1989). The micrometeorology of the urban forest. Philosophical Transactions of the Royal Society of London, 324, 335-349.

Öztürk, M. (2015). Complete intra-annual cycle of leaf area index in a Platanus orientalis L. stand. Plant Biosystems-An international journal dealing with all aspects of plant biology, DOI: 10.1080/11263504.2015.1054446.

Öztürk M, Bolat İ, Ergün A. 2015. Influence of air-soil temperature on leaf expansion and LAI of Carpinus 
betulus trees in a temperate urban forest patch. Agricultural and Forest Meteorology. 200, 185-191.

Promis, A., Schindler, D., Reif, A., Cruz, G. (2009). Solar radiation transmission in and around canopy gaps in an uneven-aged Nothofagus betuloides forest. International Journal of Biometeorology, 53, 355-367.

Schleppi, P., Conedera, M., Sedivy, I., Thimonier, A. (2007). Correcting non-linearity and slope effects in the estimation of the leaf area index of forests from hemispherical photographs. Agricultural and Forest Meteorology, 144, 236-242.

TGDF (Turkish General Directorate of Forestry). (2006). Forest management plans of Ulus Forest Administration. Ankara.

TGDMRE (Turkish General Directorate of Mineral Research and Exploration). (2007). Digital geological maps of Zonguldak F-29 Section. Ankara.

TMFAL (Turkish Ministry of Food, Agriculture and Livestock). (2005). Digital soil maps of Bartın stream watershed. Ankara.

TSMS (Turkish State Meteorological Service). (2013). Daily meteorological data. Ankara.

Tutin, T.G., Burges, N.A., Chater, A.O., Edmondson, J.R., Heywood, V.H., Moore, D.M., Valentine, D.H., Walters, S.M., Webb, D.A. 1993. Flora of Europaea, Volume: I, Psilotaceae to Platanaceae. Cambridge University Press, Cambridge, UK.

UNESCO (United Nations Educational Scientific and Cultural Organization). (1995). Convention Concerning the Protection of the World Cultural and National Heritage, Report of the World Heritage Committee Eighteenth Session. Phuket Thailand, 12-17 December 1994 pp. 113. Retrieved from - http://whc.unesco.org/archive/1994/whc94-conf003-16e.pdf

Velarde, M.D., Fry, G., Tveit, M. (2007). Health effects of viewing landscapes-Landscape types in environmental psychology. Urban Forestry \& Urban Greening, 6, 199-212.

Viles, R.L., Rosier, D.J. (2001). How to use roads in the creation of greenways: case studies in three New Zealand landscapes. Landscape and Urban Planning, 55, 15-27.

Waring, R.H., Running, S.W. (2007). Forest Ecosystems: analysis at multiple scales. 3rd edn. Elsevier Academic Press, UK.

Wolf, K.L. (2003). Freeway roadside management: the urban forest beyond the white line (Social aspects of urban forestry). Journal of Arboriculture, 29, 127-136.

Yaltırık, F., Efe, A. (2000). Dendrology, GymnospermaeAngiospermae (in Turkish). İstanbul University Press, İstanbul, Turkey.

Yu, K., Li, D., Li, N. (2006). The evolution of greenways in China. Landscape and Urban Planning, 76, 223-239.

Submitted: $23 \cdot 10.2015$

Accepted: 11.12.2015 